\title{
Habis Manis Sepah Jadi Uang: Pemanfaatan Ampas Tebu Menjadi Boneka Arang Aktif
}

\author{
Sumiati*1, Andi Muhammad Irfan Taufan Asfar ${ }^{2}$, Andi Muhamad Iqbal Akbar Asfar ${ }^{3}$, Andi Aswan, \\ Dahniar $^{5}$, Nelly Hasanuddin 6 \\ 1,2Program Studi Pendidikan Matematika, ${ }^{4}$ Program Studi Pendidikan Biologi, ${ }^{5}$ Program Studi Teknologi \\ Pendidikan ${ }^{6}$ Program Srudi Pendidikan Ekonomi, STKIP Muhammadiyah Bone \\ ${ }^{3}$ Program Doktoral Ilmu Pendidikan, Universitas Negeri Makassar \\ *e-mail:sumiatiasmah86@gmail.com ${ }^{1}$, tauvanlewis00@gmail.com², andiifalasfar@gmail.com ${ }^{3}$, \\ Andiaswan04021999@gmail.com ${ }^{4}$ Checedahniar04@gmail.com ${ }^{5}$, nellipajjai@gmail.com6
}

\begin{abstract}
In the eyes of the people in Arasoe Village, bagasse does not have a high benefit, it is only used as an embankment in a water channel or allowed to pile up. The bagasse pile is sometimes burned to reduce the quantity in the environment. However, burning bagasse waste is not effective in reducing the accumulation that occurs because the waste of sugarcane is very large and causes air pollution and the result of combustion only produces ash, if it is disposed of into the river it will pollute nature. Community empowerment in utilizing bagasse to become active puppets is a form of counseling by the community service team of STKIP Muhammadiyah Bone which is carried out online. This counseling was attended by 10 people consisting of the PKK group in Arasoe Village, China District, Bone Regency. The activities carried out were in the form of an introduction to the purpose of holding community service activities, presentation of tools and materials and the stages in making activated charcoal dolls. So that the community will be able to implement independently as the final result of this activity.
\end{abstract}

Keywords: Arasoe Village, Bagasse, Activated Charcoal Doll

\begin{abstract}
Abstrak
Ampas tebu dimata masyarakat di Desa Arasoe tidak memiliki manfaat yang tinggi, hanya dijadikan sebagai tanggul di saluran air atau dibiarkan menumpuk. Tumpukan ampas tebu kadang dibakar untuk mengurangi kuantitas dilingkungan. Namun, pembakaran limbah ampas tebu tidak efektif dalam mengurangi penumpukan yang terjadi karena limbah ampas tebu yang sangat banyak dan menimbulkan pencemaran udara dan hasil pembakaran hanya menghasilkan abu, jika dibuang ke sungai akan mencemari alam. Pemberdayaan masyarakat dalam memanfaatkan ampas tebu menjadi boneka aktif merupakan bentuk salah satu bentuk penyuluhan oleh tim pengabdian pada masyarakat STKIP Muhammadiyah Bone yang dilaksanakan secara daring. Penyuluhan ini diikuti oleh 10 orang yang terdiri dari kelompok PKK Desa Arasoe Kecamatan Cina Kabupaten Bone. Kegiatan yang dilakukan berupa pengantar tentang tujuan diadakannya kegiatan pengabdian pada masyarakat, pemaparan alat dan bahan serta tahap-tahap dalam pembuatan boneka arang aktif. Sehinggann masyarakat nantinya dapat mengimplementasikan secara mandiri sebagai hasil akhir dari kegiatan ini.
\end{abstract}

Kata kunci: Desa Arasoe, Ampas Tebu, Boneka Arang Aktif

\section{PENDAHULUAN}

Kesejahteraan masyarakat merupakan hal yang menjadi prioritas pembangunan berkelanjutan. Kesejahteraan tidak hanya dipandang dari segi kemapanan materi, namun juga mengikutsertakan aspek kenyamanan dan keamanan dalam kehidupan masyarakat. Pembangunan berkelanjutan yang tertuang dalam Sustainable Development Goal's (SDG's) 2030 memiliki harapan yang sangat kuat pada keberlanjutan hidup dengan kolaborasi yang baik antara masyarakat, pemerintah dan lingkungan (Hoelman et al., 2016).

Mengacu pada tujuan SDG's 2030 yang mengarah pada pemenuhan kebutuhan hidup manusia dengan penambahan skill dalam pengelolaan sumber daya yang ada hendaknya dapat direalisasikan. Pemberdayaan masyarakat melalui pembinaan skill pengelolaan limbah yang sebelumnya menjadi ancaman bagi kesehatan masyarakat dan lingkungan menjadi produk yang bernilai jual tinggi adalah hal yang cukup penting. Salah satu limbah yang dapat diolah sebagai 
produk yang bernilai jual tinggi yaitu ampas tebu yang dihasilkan dari sisa pengolahan pabrik gula di Desa Arasoe, Kecamatan Cina, Kabupaten Bone. Pabrik gula tersebut mampu mengolah tebu menjadi gula pasir dengan kapasitas yang cukup besar yakni 2.400 ton tebu per hari (PTPN XIV, 2017). Ampas tebu adalah limbah pabrik gula yang banyak ditemukan dan dapat mencemari lingkungan apabila tidak dimanfaatkan (Ali, Kuntoro \& Misrianti, 2019; Setiati, et al., 2016).

Selama ini, ampas tebu dimata masyarakat di Desa Arasoe tidak memiliki manfaat yang tinggi, hanya dijadikan sebagai tanggul di saluran air atau dibiarkan menumpuk dan menghasilkan bau yang menyengat. Padahal arang aktif yang berasal dari bahan baku ampas tebu memiliki kualitas yang sangat tinggi dibandingkan arang aktif dari bahan baku yang lain (Apriani, Perdana \& Saraswati, 2014). Tumpukan ampas tebu kadang dibakar untuk mengurangi kuantitas dilingkungan. Namun, pembakaran limbah ampas tebu tidak efektif dalam mengurangi penumpukan yang terjadi karena limbah ampas tebu yang sangat banyak. Selain tidak efektif, penumpukan limbah ampas tebu hanya dibakar yang menimbulkan pencemaran udara dan hasil pembakaran hanya menghasilkan abu, jika dibuang ke sungai akan mencemari alam dan akan menimbulkan masalah lain.

Oleh karena itu, penumpukan limbah ampas tebu dapat diolah menjadi suatu produk yang berguna melalui program kreativitas sebagai pengabdian mahasiswa kepada masyarakat. Akan tetapi, selama ini informasi akan pengolahan ampas tebu atau disebut pula sebagai blotong masih sangat terbatas. Sehingga, kegiatan positif melalui pengabdian kepada masyarakat melalui entitas-entitas akademika yaitu mahasiswa akan sangat membantu dalam kegiatan pemberdayaan masyarakat khususnya di Desa Arasoe.

Pelaksanaan pengabdian kemitraan masyarakat ini dilakukan society parcipatory yang dilaksanakan secara by doing (Yasser et al., 2020; Asfar, Arifuddin \& Rahman, 2019). Proses pemberdayaan adalah suatu siklus yang melibatkan masyarakat untuk bekerjasama dalam kelompok formal maupun informal untuk melakukan kajian masalah, merencanakan, melaksanakan, dan melakukan evaluasi terhadap program yang telah direncanakan bersama (Yudanto, Raharjo \& Ubed, 2018). Kegiatan yang akan dilaksanakan adalah akan melakukan pemanfaatan limbah ampas tebu yang awalnya menjadi ancaman bagi kesehatan masyarakat dan lingkungan diolah menjadi boneka arang aktif dengan melibatkan masyarakat langsung khususnya 2 kelompok PKK Desa Arasoe, untuk meningkatkan kreativitas (skill) dan kesejahteraan mereka. Kegiatan yang akan dilakukan yaitu pemanfaatan ampas tebu sebagai boneka arang aktif yang memiliki tingkat estetika yang tinggi dan juga berguna sebagai adsorben polusi udara. Pengolahan ini, disamping memanfaatkan ampas tebu menjadi boneka arang aktif, dapat pula mengatasi limbah ampas tebu yang semakin menumpuk. Jika boneka ini dijual oleh mitra maka akan meningkatkan kesejahteraan mereka. Pada akhirnya, kegiatan kemitraan masyarakat ini akan berguna dalam memberdayakan masyarakat desa khususnya Desa Arasoe.

\section{METODE PELAKSANAAN}

Metode pelaksanaan kegiatan pengabdian kepada masyarakat tentang pemanfaatan ampas tebu menjadi boneka arang aktif di Desa Arasoe, merupakan sebuah rangkaian tahapan yang disusun secara sistematis. Penyuluhan kepada mitra dilakukan secara daring dengan pembahasan terkait alat dan bahan serta langkah-langkah pembuatan ampas tebu menjadi boneka arang aktif.

Alur pelaksanaan kegiatan pengabdian kepada masyarakat terkait pembuatan boneka arang aktif, yaitu:

1. Persiapan Internal yang meliputi:

a. Rapat penentuan pelaksanaan kegiatan;

b. Pengkajian kesiapan tim;

c. Evaluasi hasil pengkajian.

2. Observasi Lapangan dan Perizinan yang meliputi: 

a. Visitasi daerah sasaran;
b. Observasi kondisi mitra dan lingkungan sasaran;
c. Bertukar pikiran dengan mitra mengenai permasalahan yang dirasakan;
d. Perizinan dan surat pernyataan kesediaan kerjasama dari mitra;
e. Perizinan kepada kepala desa;

3. Persiapan dan Pelaksanaan kegiatan yang meliputi:
a. Penyuluhan program kegiatan;
b. Pengadaan alat dan bahan; dan
c. Membuat rancangan desain produksi;
d. Pelatihan pembuatan produk kepada mitra.

4. Pengontrolan Program yang meliputi:
a. Pendampingan, pengontrolan dan uji laboratorium arang aktif untuk merujuk pada standar SNI Arang Aktif yaitu SNI 06-3730-1995;
b. Pengontrolan setelah proses produksi; serta
c. Pelatihan manajemen keuangan dan pemasaran.

5. Evaluasi keseluruhan yang bertujuan untuk mengukur serta melihat kemajuan maupun kekurangan kegiatan. Evaluasi termasuk pula dalam kegiatan pendampingan kepada mitra terkait hal-hal teknis yang dialami mitra selama peneraparan yaitu pengolahan ampas tebu menjadi boneka arang aktif. Sehingga, melalui pendampingan diharapkan mitra dapat mandiri dalam mengolah ampas tebu secara maksimal.

6. Publikasi dan laporan akhir dari pelaksanaan program kegiatan yaitu melaporkan segala bentuk aktivitas baik yang bersifat terstruktur maupun non struktural dalam bentuk laporan kemajuan dan laporan akhir pelaksanaan kegiatan ini.

Secara garis besar, alur kegiatan pengabdian kepada masyarakat ini terdiri atas empat langkah utama yang tertuang pada gambar berikut:

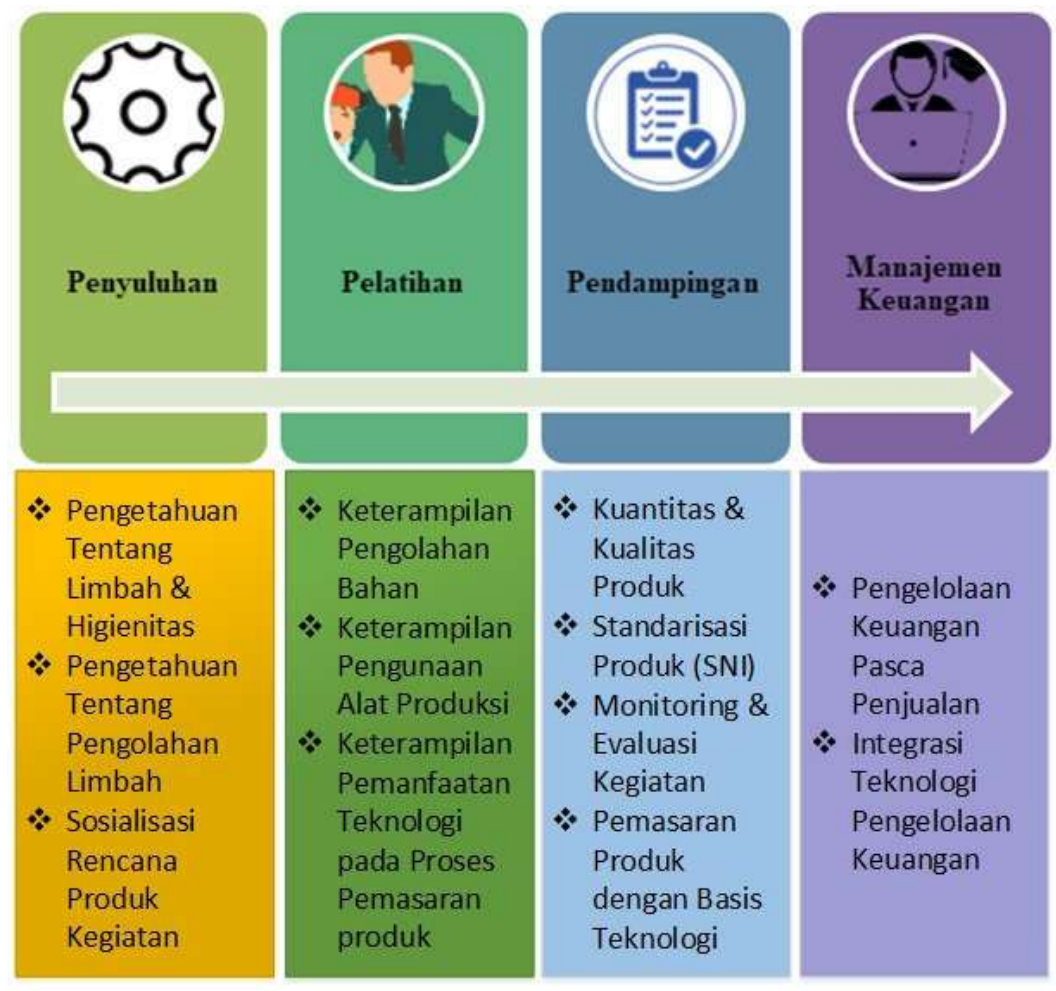

Gambar 1. Alur Pelaksanaan Kegiatan Pengabdian Kepada Masyarakat 


\section{HASIL DAN PEMBAHASAN}

\subsection{Penyuluhan}

Kegiatan penyuluhan sebagai pelaksanaan program kemitraan masyarakat yang dilakukan secara daring sebagai bentuk sosialisasi kepada mitra dan warga Desa Arasoe. Latar belakang dan manfaat kegiatan pengabdian pada masyarakat, gambaran umum masyarakat tentang potensi Desa Arasoe dan tata cara pembuatan boneka arang aktif merupakan materi penyuluhan pengabdian kepada masyarakat. Ringkasan materi pengabdian diuraikan sebagai berikut.

\section{Latar belakang}

Ampas tebu selama ini dimata masyarakat di Desa Arasoe tidak memiliki manfaat yang tinggi, hanya dijadikan sebagai tanggul di saluran air atau dibiarkan menumpuk dan menghasilkan bau yang menyengat. Padahal arang aktif yang berasal dari bahan baku ampas tebu memiliki kualitas yang sangat tinggi dibandingkan arang aktif dari bahan baku yang lain. Tumpukan ampas tebu kadang dibakar untuk mengurangi kuantitas dilingkungan. Namun, pembakaran limbah ampas tebu tidak efektif dalam mengurangi penumpukan yang terjadi karena limbah ampas tebu yang sangat banyak. Selain tidak efektif, penumpukan limbah ampas tebu hanya dibakar yang menimbulkan pencemaran udara dan hasil pembakaran hanya menghasilkan abu, jika dibuang ke sungai akan mencemari alam dan akan menimbulkan masalah lain.

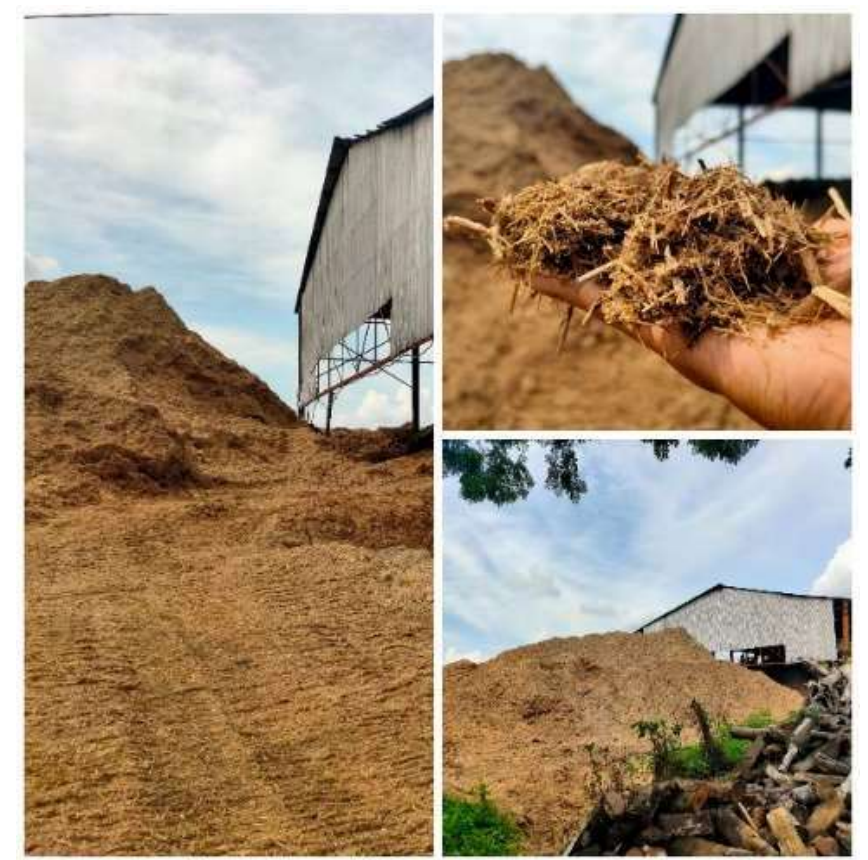

Gambar 2. Tumpukan Ampas Tebu Buangan Produksi Gula

\section{Kondisi Masyarakat}

Kelompok PKK Desa Arasoe menjadi sasaran pelaksanaan kegiatan pemanfaatan limbah ampas tebu menjadi boneka arang aktif karena mayoritas kelompok PKK Desa Arasoe memiliki banyak waktu luang. Selain itu, beberapa masyarakat juga menghuni kompleks perumahan PTPN XIV. Pemanfaatan limbah ampas tebu menjadi boneka arang aktif ini diharapkan mampu memotivasi kelompok PKK Desa Arasoe menjadi lebih kreatif dalam menciptakan produk baru yang berkualitas dengan tingkat estetika tinggi dan dapat meningkatkan kesejahteraan mitra.

\section{Kondisi dan Potensi Wilayah}

Desa Arasoe, Kecamatan Cina, Kabupaten Bone, Provinsi Sulawesi Selatan, memiliki luas $15,15 \mathrm{~km}^{2}$ atau sebesar $10,27 \%$ dari total luas Kecamatan Cina. Terletak pada daerah dataran rendah dengan ketinggian $37 \mathrm{mdpl}$. Jarak antara desa Arasoe dengan ibu kota kecamatan sejauh 
$7 \mathrm{~km}$, sedangkan jarak dari Desa Arasoe dengan ibu kota kabupaten sejauh $23 \mathrm{~km}$.Jumlah penduduk sebanyak 3.475 jiwa, populasi laki-laki sebanyak 1.730 jiwa dan perempuan sebanyak 1.745 jiwa kepadatan penduduk 229 jiwa $/ \mathrm{km}^{2}$ (Badan Pusat Statistik Kabupaten Bone, 2019).

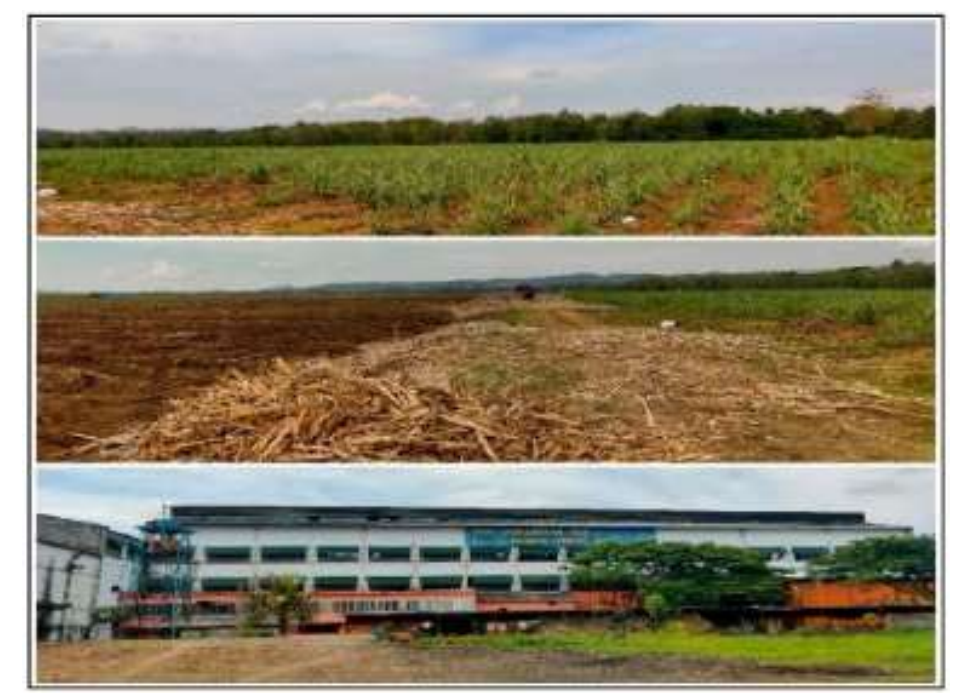

Gambar 3. Areal Pertanian dan Pabrik Gula Tebu di Desa Arasoe

Desa Arasoe merupakan daerah agraris (pertanian) tanaman tebu dan industry pabrik gula tebu. Terdapat 1 unit pabrik gula tebu yang dikelola oleh PTPN XIV yang beroperasi menghasilkan sisa ampas tebu yang sangat banyak dan hanya menumpuk tanpa ada pemanfaatan yang berarti. Ampas tebu yang menumpuk sudah cukup banyak dan juga mencemari sungaisungai yang ada di dekat pabrik, sehingga estetika pabrik tidak terjaga dengan baik serta menimbulkan dampak lain yang lebih berbahaya bagi ekosistem dan lingkungan.
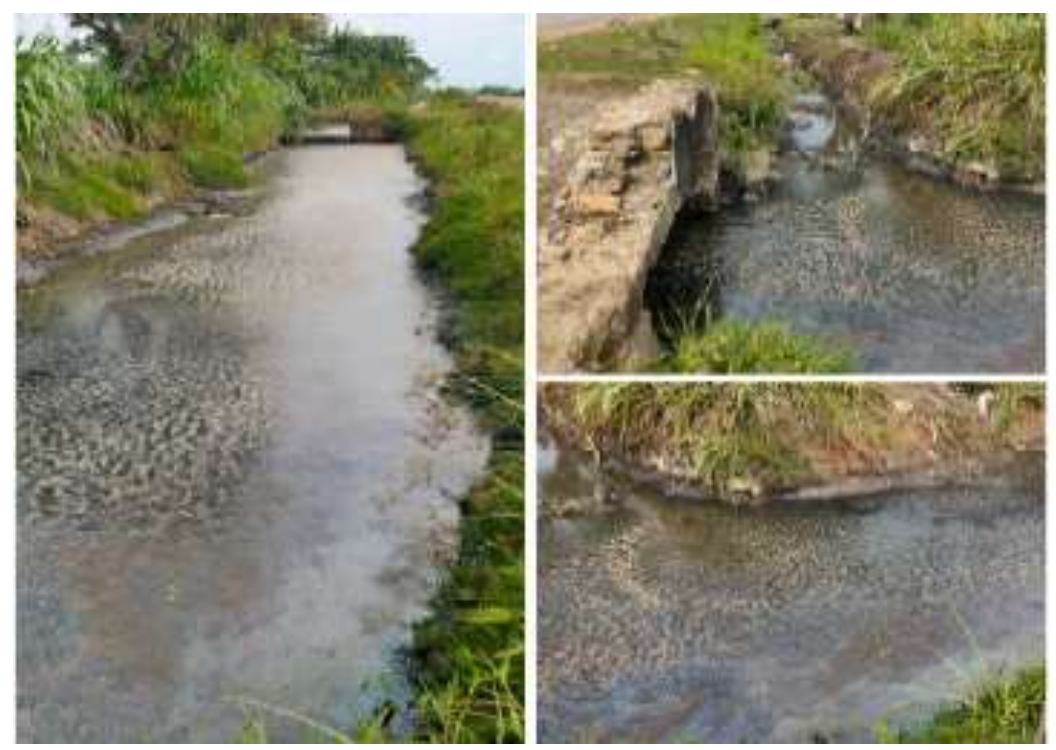

Gambar 4. Saluran Irigasi yang Tercemar Limbah Pabrik Gula

\subsection{Pelatihan}

Pelatihan dalam kgiatan ini yaitu tata cara pembuatan boneka arang aktif dari ampas tebu. Proses pembuatan produk boneka arang aktif berbahan ampas tebu sebagai berikut:

1. Pembuatan Arang

a. Membersihkan ampas tebu dan memasukkan ke dalam tungku drum modifikasi hingga penuh; 
b. Menutup tungku drum modifikasi dan bakar pada bagian dasar selama 3-5 jam hingga asap pada cerobong tungku habis;

c. Mendinginkan tungku selama 3-5 jam;

d. Mengeluarkan arang dari drum; dan

e. Menghaluskan arang dengan mesin penepung.

2. Pengaktifan Arang

Secara garis besar, ada 3 tahap pembuatan karbon aktif, yaitu :

a. Merendam arang di dalam larutan aktivator $\mathrm{CaCl} 2$ 0,2M selama 18 jam;

b. Dari langkah di atas didapat pasta arang;

c. Menyaring arang dengan kertas saring, kemudian mencuci dengan aquades hingga pH 7;

d. Mengeringkan arang dalam oven pada suhu 150 oC selama 2 jam; dan

e. Mengayak arang aktif kering dengan ayakan mesh 200 .

3. Pengujian laboratorium untuk merujuk pada SNI 06-3730-1995 Arang Aktif

4. Pengemasan Arang Aktif

a. Mengemas bubuk arang aktif ke dalam kertas pembungkus silika ukuran $5 \mathrm{~cm} \times 8 \mathrm{~cm}$ (berat \pm 20 gram); dan

b. Mengelem bagian atas dan bawah pembungkus agar bubuk arang aktif tidak tumpah.

5. Pembuatan Boneka

a. Menggambar pola desain boneka pada kertas karton;

b. Menggunting kain velboa mengikuti pola;

c. Menjahit kain pola;

d. Memasukkan dakron melalui bagian resleting hingga separuh penuh;

e. Memasukkan 2 bungkus bubuk arang aktif ke dalam boneka;

f. Memenuhi bagian dalam boneka dengan dakron dan tambahkan aksesoris hingga terbentuk boneka yang diinginkan; dan

g. Menjahit kembali bagian yang terbuka hingga tertutup secara sempurna.

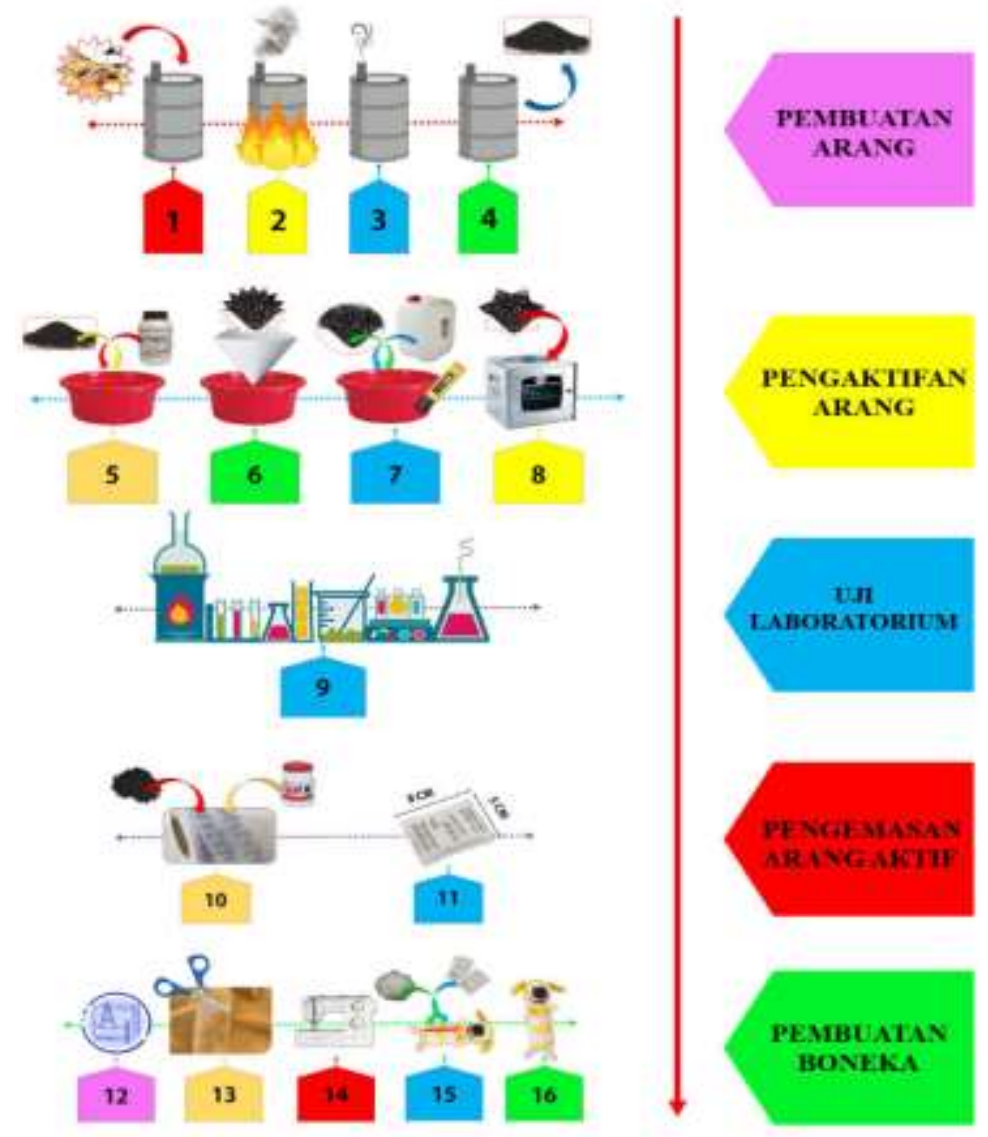

Gambar 5. Tahapan Pembuatan Boneka Arang Aktif 


\subsection{Pendampingan}

Permasalahan Desa Arasoe dapat dikenali setelah pelatihan dilaksanakandari pendampingan ini. Sebagaimana yang dinyatakan oleh Yasser et al (2020) bahwa pendampingan dilaksanakan untuk mengevaluasi kemampuan mitra dalam membuat sekaligus kemampuan mitra akan mengembangkan produk yang dihasilkan.

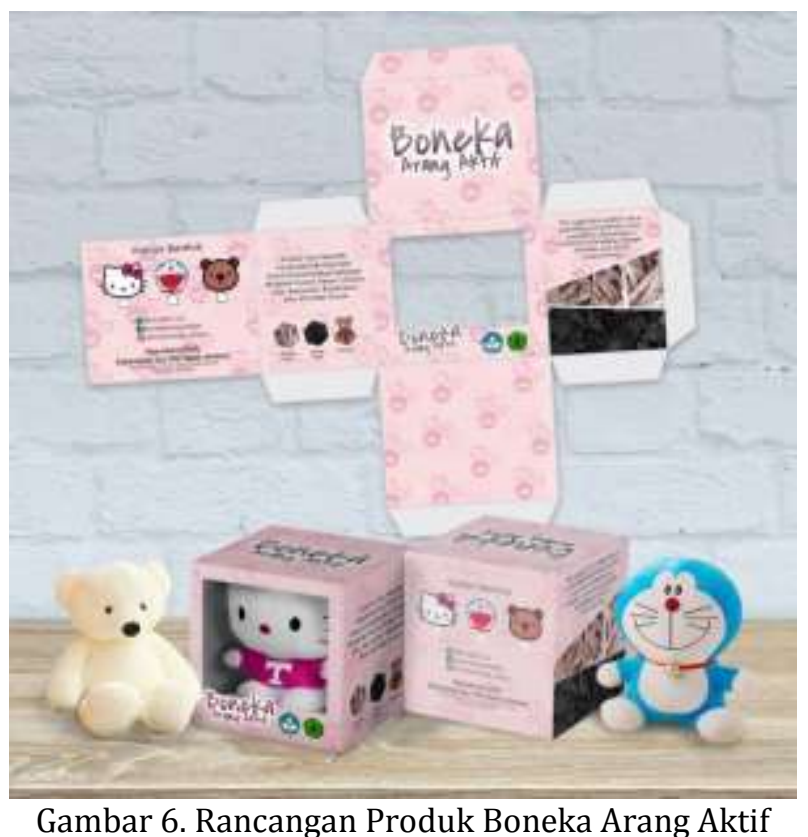

\section{KESIMPULAN}

Dengan dilaksanakan program pengabdian masyarakat dalam melakukan pemanfaatan ampas tebu menjadi boneka arang aktif:

1. Mitra terampil dalam mengolah ampas tebu menjadi produk boneka arang aktif;

2. Mitra mampu mengoperasikan alat untuk pembuatan boneka arang aktif;

3. Program Kemitraan Masyarakat ini telah berhasil menyelesaikan permasalahan mitra akan ampas tebu yang menumpuk tanpa terolah dengan baik, serta mencemari sungaisungai yang ada di dekat pabrik.

\section{UCAPAN TERIMA KASIH}

Penulis menyampaikan terima kasih kepada Direktorat Pembelajaran dan Kemahasiswaan Dirjen Pendidikan Tinggi Kemendikbud atas pendanaan PKM-5 Bidang pendanaan tahun 2020, Mitra Kelompok PKK Desa Arasoe, Pemerintah Kecamatan Cina Kabupaten Bone, STKIP Muhammadiyah Bone serta Dosen dan Staf, yang telah membantu dalam penyusunan penulisan ini.

\section{DAFTAR PUSTAKA}

Afar, AMIA., Arifuddin, W., \& Rahman, A. 2019. Pengolahan Kayu Seppang (Caesalpinia sappan L.) di Desa Biru Kecamatan Kahu Kabupaten Bone Sulawesi Selatan. Jurnal Panrita Abdi, 3(2), 97104.

Ali, A., Kuntoro, B., \& Misrianti, R. 2019. Kandungan Fraksi Serat Tepung Silase Ampas Tebu yang Ditambah Biomasa Indigofera Sebagai Pakan. Jurnal Peternakan, 16(1), 10-17. 
Apriani, W., Perdana, I. \& Saraswati, S.P. 2014. Pengaruh jenis arang aktifampas tebu, tatal kayu dan tempurung kelapa terhadap kemampuan penjerapan warna air sungai Sambas. ASEAN Journal of Systems Engineering. 2 (2):59-64.

Badan Pusat Statistik Kabupaten Bone. 2019. Kecamatan Cina dalam Angka 2019. BPS Kabupaten Bone. Bone.

Hoelman, M.B., Parhusip, B.T.P., Eko, S., Bahagijo, S. \& Santono, H. 2016. Sustainable Development Goals-SDG's : Panduan untuk Pemerintah Daerah (Kota dan Kabupaten) dan Pemangku Kepentingan Daerah. INFID: International NGO Forum on Indonesian Development. Jakarta.

PTPN XIV. 2017. Laporan Manajemen Tahunan Tahun Buku 2016. Makassar.

Ramdja, A.F., Halim, M. \& Handi, J. 2008. Pembuatan karbon aktif dari pelepah kelapa (cocos nucifera). Jurnal Teknik Kimia. 15 (2):1-8.

Setiati, R., Wahyuningrum, D., \& Siregar, S., \& Marhaendrajana, T. 2016. Optimasi Pemisahan Lignin Ampas Tebu dengan Menggunakan Natrium Hidroksida. Ethos (Jurnal Penelitian dan Pengabdian Masyarakat. 4(2), 257-264.

Yasser, M., Asfar, AMIA., Asfar, AMIT., Rianti M., \& Budianto, E. (2020). Pengembangan Produk Olahan Gula Merah Tebu dengan Pemanfaatan Ekstrak Herbal di Desa Latellang Kabupaten Bone. Jurnal Panrita Abdi, 4(1), 42-51.

Yudanto, A. A., Raharjo, T., \& Ubed, R. S. 2018. Pendampingan Pengembangan Produk Unggulan Kawasan Perdesaan pada Usaha Berbasis Komunitas Desa Cibogo. DINAMISIA: Jurnal Pengabdian Kepada Masyarakat, 2(2), 341-346. 